\title{
Growth, body state and breeding performance in gilts and primiparous sows
}

\author{
F.P. Bortolozzo', M.L. Bernardi' ${ }^{2}$ R. Kummer ${ }^{3}$ and I. Wentz ${ }^{1}$ \\ ' Department of Animal Medicine, Veterinary Faculty, Federal University of Rio Crande do Sul, \\ Avenida Bento Gonçalves, 9090, CEP 91540-000 Porto Alegre-RS, Brazil; ${ }^{2}$ Department of Animal \\ Science, Agronomy Faculty, Federal University of Rio Grande do Sul, Avenida Bento Conçalves, \\ 7712, CEP 91540-000 Porto Alegre-RS, Brazil; ${ }^{3}$ Master Agropecuária Ltda, Rua Constantino Crestani, \\ 639, CEP 89560-000 Videira-SC, Brazil
}

\begin{abstract}
Optimizing gilt management is a critical point to improve breeding herd efficiency. This review describes the effects of growth rate (GR) and body state at onset of puberty stimulation or at first mating on gilt puberty attainment, productivity and sow longevity. Traditional management practices should be re-evaluated with attention to different modern genotypes. It is difficult to discern the real effects of age, weight, backfat depth and estrus number at first insemination on longevity and reproductive performance, because these variables affect one another. GR interacts with age at boar exposure to influence age at puberty. Higher lifetime GR gilts $(>700 \mathrm{~g} / \mathrm{d})$ attain puberty earlier and have a lower anoestrus rate. If gilts attain a target weight $(135-150 \mathrm{~kg})$, are adapted to herd health status and have at least one previously recorded estrus, they can be inseminated. Overweight at first breeding and throughout gestation should be avoided. There is no advantage in breeding gilts heavier than $150 \mathrm{~kg}$; at first farrowing the target weight is $180-185 \mathrm{~kg}$. Piglet production at first parity may be increased in gilts with a high GR but the number of stillborn piglets can also be increased. The culling rate over 3 parities for locomotion problems, which is one of the major risk factors for reduced herd retention rate, can be increased in overweight gilts at first breeding (>150-170 kg).
\end{abstract}

\section{Introduction}

Gilts and primiparous sows are the largest farrowing group in pig farms. Implementing an effective gilt pool management strategy is a fundamental tool to achieve targets for body condition and physiological maturity. The efficiency with which gilts are introduced to the breeding herd has a major impact on breeding herd efficiency. A constant flow of high quality and well managed gilts into the breeding herd will increase sow longevity, stabilize the parity structure of the breeding herd and allow the farm to achieve weekly breeding targets.

Modern genotypes are more sensitive to nutritional mismanagement than their predecessors, as they have less appetite and lower energy reserves at the beginning of their productive lives (Whittemore 1996). To achieve breeding targets and to make gilts as highly productive as possible, it is important to recognize the key physiological characteristics of contemporary dam-line females, and particularly their exceptional lean growth potential. Unfortunately, the 
major changes in lean growth potential and associated changes in overall tissue metabolism of contemporary dam-line sows are still not adequately recognized (Foxcroft et al. 2005).

Traditional management practices that were established even 20 years ago need to be reevaluated if we are to capture the full economic potential of the modern breeding sow and her offspring, in terms of greatly improved nutrient utilization (Foxcroft et al. 2005). Even after re-evaluating these practices for modern genotypes, some peculiarities among the wide variety of animals available from the various breeding companies are expected.

Potential efficiency of the breeding herd increases as the number of non-productive days associated with gilt development decreases. To choose the right moment to introduce and breed gilts, the cost of production, potential first and second parity total born, farrowing rate, retention rate, sow longevity and lifetime productivity must be taken into account.

Although replacement gilts can enter a herd at various ages and with different management practices, they need to be managed correctly from birth through their first lactation. The successful development of replacement gilts requires the integration of health, nutrition, genetics, housing and management practices. Thus, an excellent gilt development program will reduce replacement costs of multiparous sows. The objective of this paper is to review the effects of growth rate (GR) and body state on puberty onset, productivity and sow longevity.

\section{Growth rate and age at puberty}

The occurrence of puberty can be stimulated at younger ages by several environmental and management factors, but associations between puberty and a critical weight (Prunier et al. 1987, Newton \& Mahan 1992), GR (King 1989, Beltranena et al. 1991, Beltranena et al. 1993), lean tissue (Patterson et al. 2002) and backfat depth or body fat percentage (Newton \& Mahan 1992, Rozeboom et al. 1995, Gaughan et al. 1997) are still controversial. The interaction among corporal characteristics and other factors such as breed, age, boar effect, season and environment, which also affect puberty attainment (Evans \& O'Doherty 2001), is not clearly understood. An increased potential for lean tissue deposition and an associated lack of fatness in the modern genotypes could change the minimum level of leanness or fat, or ratio of fat to lean to attain puberty. Such a selection trend indicates that traditional management practices established with old genotypes should be re-evaluated.

Earlier data (Beltranena et al. 1991) suggested that only when GR was below $0.55 \mathrm{~kg} /$ day from birth to boar stimulation onset at 160 days of age was there a delay on pubertal estrus. Recent data support that with unrestricted feeding during the prepubertal period (growth/finish phase) and recommended space allocations during development, it is unlikely that GR in modern genotypes will limit age at onset of first estrus (Foxcroft et al. 2005, Amaral Filha et al. 2009). It should be emphasized that boar contact at an appropriate age will exert a great influence and play a critical role on puberty attainment. The onset of boar contact at a younger age decreases age at puberty but requires a longer period of stimulation. On the other hand, older gilts at boar exposure onset are typically older at puberty, require fewer days of stimulation and are more synchronized at first heat (Van Wettere et al. 2006, Amaral Filha et al. 2009).

In a well managed farm, approximately $85 \%$ of gilts should attain puberty within 3 or 4 weeks after boar exposure (Foxcroft et al. 2005). Kummer et al. (2009) observed that higher GR gilts ( $723 \mathrm{~g} /$ day) stimulated at approximately 144 days of age showed puberty nine days earlier ( 155 vs 164 days of age) than lower GR gilts (577 g/day) with more of them attaining puberty by 190 days of age $(95 \%$ vs $76 \%)$. The fact that $95 \%$ of the heavier gilts showed estrus by 190 days of age indicates the importance of pre-pubertal GR as a factor influencing puberty mainly when gilts are exposed to boars at an early age. Amaral Filha et al. (2009) described the effect 
of the interaction between age at boar exposure (142 vs 157 days of age on average) and GR on puberty attainment. It was shown that puberty onset of high GR females ( $>725 \mathrm{~g} / \mathrm{d}$ ) when gilts were stimulated at 130-149 days of age was earlier than low GR females (550-649 $\mathrm{g} / \mathrm{d})$. In contrast, if gilts were submitted to boar exposure at an older age (150-170 days), no influence of GR on puberty age was observed (Table 1). High GR gilts are likely to be physiologically more mature at younger ages in terms of possible minimums in threshold weight, lean:fat ratio, fatness or rate of body reserve accumulation (Hughes 1982, Kirkwood \& Aherne 1985), which are necessary for responsiveness to boar contact.

Table 1. Cumulative percentage of gilts showing the pubertal estrus and age at puberty according to growth rate and age at the onset of boar exposure.

\begin{tabular}{|c|c|c|c|c|c|c|}
\hline \multirow[b]{3}{*}{ Growth rate, $g / d$} & \multicolumn{6}{|c|}{ Age at boar exposure } \\
\hline & \multicolumn{3}{|c|}{$130-149$ days } & \multicolumn{3}{|c|}{ 150-170 days } \\
\hline & $550-649$ & $650-725$ & $726-830$ & $550-649$ & $650-725$ & $726-830$ \\
\hline Number of gilts & 170 & 400 & 181 & 201 & 349 & 185 \\
\hline Estrus by $10 \mathrm{~d}, \%$ & $27.6 a$ & $29.0 a$ & $38.1 \mathrm{~b}$ & $44.3 b$ & $45.3 \mathrm{~b}$ & $43.2 \mathrm{~b}$ \\
\hline Estrus by $20 \mathrm{~d}, \%$ & $48.2 a$ & $48.7 a$ & $59.7 b$ & $63.7 \mathrm{~b}$ & $67.3 b$ & $63.8 \mathrm{~b}$ \\
\hline Estrus by $30 \mathrm{~d}, \%$ & $70.6 \mathrm{ab}$ & $67.5 a$ & $76.2 \mathrm{bc}$ & $83.6 \mathrm{c}$ & $81.7 \mathrm{C}$ & $82.7 c$ \\
\hline Estrus by $40 \mathrm{~d}, \%$ & $82.3 \mathrm{ac}$ & $79.2 \mathrm{a}$ & $85.6 a b$ & $88.6 b c$ & $89.7 b$ & $89.2 \mathrm{bc}$ \\
\hline Pubertal females, \% & $90.0 a$ & $89.2 a$ & $91.7 \mathrm{a}$ & $93.0 \mathrm{a}$ & $93.1 \mathrm{a}$ & $96.2 \mathrm{a}$ \\
\hline $\begin{array}{l}\text { Puberty age, } d \\
( \pm \text { SE) }\end{array}$ & $\begin{array}{l}164.8 \mathrm{a} \\
(1.11)\end{array}$ & $\begin{array}{c}162.2 \mathrm{ab} \\
(0.76)\end{array}$ & $\begin{array}{l}159.6 b \\
(1.03)\end{array}$ & $\begin{array}{l}172.1 \mathrm{c} \\
(1.07)\end{array}$ & $\begin{array}{l}171.5 c \\
(0.81)\end{array}$ & $\begin{array}{l}174.0 \mathrm{c} \\
(1.17)\end{array}$ \\
\hline
\end{tabular}

Different letters, in the row, indicate significant differences $(P<0.05)$.

(Amaral Filha et al. 2009).

It seems possible that feed restriction may influence the relationship between $G R$ and age at puberty (Beltranena et al. 1991; Rozeboom et al. 1995). Beltranena et al. (1991) reported a quadratic relationship between lifetime GR and age at puberty, suggesting that gilts that gained more than $600 \mathrm{~g} / \mathrm{d}$ may have late puberty. However, age at puberty was not quadratically or linearly related to GR from birth to puberty in another study (Rozeboom et al. 1995). Discrepancy between studies may be related to the fact that the curve of Beltranena et al. (1991) was derived using both restricted and full-fed gilts, whereas all gilts were provided ad libitum access to feed in the study of Rozeboom et al. (1995). Indeed, when considered separately, average daily gain of full-fed gilts was not related to age at puberty in the study of Beltranena et al. (1991). Although low, Kummer et al. (2009) found a negative correlation between age at puberty and $G R$ from birth to 165 days $(r=-0.36, P=0.0002)$. There was also a low association in the work of Amaral Filha et al. (2009), being significant only for gilts stimulated prior to 150 days of age. GR from birth to $134 \mathrm{~kg}$ of body weight (BW), in Landrace $x$ Yorkshire gilts, was also negatively correlated $(r=-0.40, \mathrm{P}<0.001)$ with age at first observed estrus (Tummaruk et al. 2009). However, puberty was attained at about 200 days of age and average GR was $583 \pm 56$ $\mathrm{g} / \mathrm{d}$, which is in agreement with previous findings in the same breed of gilts (Tummaruk et al. 2007), but with a larger variation on puberty age and GR compared with other studies (Amaral Filha et al. 2009, Kummer et al. 2009). These variations could be explained by differences in the genetics between experiments and also by many management factors, specially the boar stimulation protocol.

Taken together, these results show that GR close to $800 \mathrm{~g} / \mathrm{d}$ has no detrimental effect on puberty onset. Other authors also suggest that when GR is higher than $620 \mathrm{~g} / \mathrm{d}$ (Kirkwood \& Thacker 1992) or at commercially acceptable GR $(550$ to $800 \mathrm{~g} / \mathrm{d})$ from birth to $100 \mathrm{~d}$ of age, puberty seems not to be limited by GR (Foxcroft eț al. 2005). 


\section{Effect of growth rate on conception rate and litter size}

Increasing GR by $100 \mathrm{~g} / \mathrm{d}$, in the first 100 days of life, has resulted in an increase of 0.3 piglets born, an earlier return to estrus after weaning and a greater farrowing rate (Tummaruk et al. 2001). Comparing two groups of gilts according to their GR from birth to 144 days of age (average $G R$ of 577 and $724 \mathrm{~g} / \mathrm{d}$ ), no differences were observed in the pregnancy rate, ovulation rate, total and viable embryos, and embryo survival rate at 32 days of gestation (Kummer et al. 2009). However, it should be pointed out that $19 \%$ of gilts with lower GR were culled for anoestrus compared with $3.4 \%$ of high GR gilts $(P<0.01)$. In commercial farms, these anoestrus gilts would probably have been reallocated or hormonally treated to stimulate their first estrus, resulting in a possible drop in reproductive performance and increase of non productive days.

Using the minimum GR $(726 \mathrm{~g} / \mathrm{d})$ and weight $(95 \mathrm{~kg})$ observed in high GR gilts (Amaral Filha et al. 2009) combined with boar stimulation at an early age (130-149 days), the expectation is that even the lightest gilt will still reach a weight around $139 \mathrm{~kg}$ by its third estrus, and remain within the range of 135-150 kg considered as ideal for the first mating (Williams et al. 2005). Conversely, the weight of high GR gilts receiving boar stimulation later (150-170 days) ranged from 110 to $134 \mathrm{~kg}$ at the start of boar contact, implying that most of these gilts could become overweight by the time of breeding at their second or third estrus. It has been suggested that high $G R$ may result in negative effects on the physical fitness of replacement gilts, and on welfare and culling rates of higher parity sows (Foxcroft \& Aherne 2001). To overcome the problem of excessive weight, gilts with a high GR could receive boar stimulation earlier. Since culling rate and reproductive performance over three parities are not compromised in gilts with a GR $\geq 700 \mathrm{~g} / \mathrm{d}$ when mated 25 days younger (Kummer et al. 2006), the advancement of first mating in high GR gilts can be suggested. Therefore, healthy and adapted gilts which have a BW of 130 to $150 \mathrm{~kg}$ and two estrous cycles can be mated regardless of age or backfat thickness (BT). It has been reported that there is no advantage in breeding gilts at greater than $150 \mathrm{~kg}$ body weight. From a practical standpoint, high GR gilts should be bred earlier (Kummer et al. 2006) or nutritional strategies could be used during the growing phase to reduce their GR. In situations where gilts are bred at greater than $150 \mathrm{~kg}$, strategies can be used during gestation to manipulate the GR of the sows up to first parity.

Recently, Amaral Filha (2009) categorized gilts that were inseminated at an average of $3.5 \pm$ 0.6 estrous cycles and about 220 days of age into three groups according to the GR from birth until first mating (Table 2). Farrowing rate and return to estrus were not affected by GR groups. GRII and GRIII females had greater litter size compared to GRI gilts, but there was no difference among GR groups in the number of piglets born alive. Nevertheless, GRIII females had a higher percentage of stillborns than GRI and GRII females (Table 2). Young et al. (2008) also verified that gilts with highest $G R(>860 \mathrm{~g} / \mathrm{d}$ ) had more total piglets born but more stillborns than gilts with $G R<680,680-770$ and $770-860 \mathrm{~g} / \mathrm{d}(0.96,0.64,0.64$, and 0.74 stillborns, respectively). A higher number of intrapartum stillborns in high GR gilts could be related to their excessive weight at farrowing being associated with prolonged farrowing (Muirhead \& Alexander 1997). Another possible reason for increasing intrapartum stillborns could be variation in birth weight. The higher coefficient of variation (CV) for birth weight, the higher percentage of litters with $\mathrm{CV}$ of birth weight $>20 \%$ and the greater number of piglets with weight $<1200 \mathrm{~g}$ observed in highest GR gilts probably contributed to their greater stillbirth rate (Table 2). Because birth weight is an important indicator of pre-weaning piglet survival and birth weight variation has been associated with changes in weaning weight (Milligan et al. 2002, Quiniou et al. 2002, Gondret et al. 2005, Wolf et al. 2008), it seems reasonable to avoid an excessive weight at mating to minimize birth weight variation. 
Table 2. Reproductive and production traits for gilts grouped according to growth rate (GR) from birth until first mating ( \pm SE)

\begin{tabular}{|c|c|c|c|}
\hline & \multicolumn{3}{|c|}{ Groups of growth rate, $g / d$} \\
\hline & $\begin{array}{c}\text { CRI } \\
(600-700 \mathrm{~g} / \mathrm{d})\end{array}$ & $\begin{array}{c}\text { GRII } \\
(701-770 \mathrm{~g} / \mathrm{d})\end{array}$ & $\begin{array}{c}\text { GRIII } \\
(771-870 \mathrm{~g} / \mathrm{d}) \\
\end{array}$ \\
\hline Return to estrus rate, $\%(n / n)$ & $6.4 \mathrm{a}(22 / 345)$ & $6.2 \mathrm{a}(44 / 710)$ & $6.0 \mathrm{a}(22 / 366)$ \\
\hline Adjusted farrowing rate ${ }^{*}, \%(n / n)$ & $92.6 \mathrm{a}(315 / 340)$ & $92.7 \mathrm{a}(651 / 702)$ & $93.6 a(339 / 362)$ \\
\hline Total born, $n$ & $12.0 \pm 0.16 a$ & $12.5 \pm 0.11 b$ & $12.9 \pm 0.15 b$ \\
\hline Born alive, $n$ & $10.9 \pm 0.16 a$ & $11.3 \pm 0.12 a$ & $11.3 \pm 0.17 \mathrm{a}$ \\
\hline Total stillborn, \% & $5.5 \pm 0.61 \mathrm{a}$ & $6.1 \pm 0.44 a$ & $8.7 \pm 0.83 b$ \\
\hline Prepartum Stillborn, \% & $0.8 \pm 0.15 a$ & $1.0 \pm 0.12 a$ & $1.3 \pm 0.21 \mathrm{a}$ \\
\hline Intrapartum Stillborn, \% & $4.7 \pm 0.59 a$ & $5.1 \pm 0.41 \mathrm{a}$ & $7.2 \pm 0.74 b$ \\
\hline Mummified, \% & $2.8 \pm 0.28 a$ & $3.2 \pm 0.25 a$ & $3.7 \pm 0.38 \mathrm{a}$ \\
\hline Females weighed at farrowing & 282 & 551 & 290 \\
\hline Weight at farrowing, kg & $196 \pm 0.71 \mathrm{a}$ & $206 \pm 0.56 b$ & $217 \pm 0.75 c$ \\
\hline Net weight gain during gestation, $\mathrm{kg}$ & $49.2 \pm 0.68 a$ & $46.4 \pm 0.51 b$ & $44.8 \pm 0.75 b$ \\
\hline Backfat thickness at farrowing, $\mathrm{mm}$ & $16.6 \pm 0.16 a$ & $17.0 \pm 0.12 \mathrm{ab}$ & $17.3 \pm 0.16 b$ \\
\hline Litters weighed, $n$ & 280 & 553 & 286 \\
\hline $\mathrm{CV}^{* *}$ for birth weight (BW), \% & $15.9 \pm 0.38 \mathrm{a}$ & $17.1 \pm 0.28 b$ & $18.1 \pm 0.37 \mathrm{~b}$ \\
\hline Litters with $\mathrm{CV}$ for $\mathrm{BW}>20, \%(n)$ & $25.0(70) \mathrm{a}$ & $29.3(162) \mathrm{a}$ & $36.4(104) \mathrm{b}$ \\
\hline Piglets with weight $<1200 \mathrm{~g}$ & $2.5 \pm 0.17 \mathrm{a}$ & $2.8 \pm 0.12 \mathrm{ab}$ & $3.1 \pm 0.17 \mathrm{~b}$ \\
\hline
\end{tabular}

$a, b, c$ different letters indicate difference in the same row $(P<0.05)$.

* Calculated by excluding dead females and females removed for non reproductive reasons.

** Coefficient of Variation

(Adapted from Amaral Filha 2009).

\section{Effect of weight at first mating or at farrowing on performance over multiple parities and lactational catabolism}

Because gilts bred with less than $135 \mathrm{~kg}$ have less total piglets born over 3 parities than gilts weighing over $135 \mathrm{~kg}$, this weight seems to be the minimum necessary at first service to allow gilts have a proper body mass at first farrowing, assuming a weight gain of 35 to $40 \mathrm{~kg}$ during first gestation (Williams et al. 2005). Kummer et al. (2006) observed that high GR gilts ( $\geq 700 \mathrm{~g} /$ day) could be inseminated at an early age (185 to 210 days) without impairing their productive performance over three parities. After grouping gilts according to their weight at first service $(130-150 \mathrm{~kg}, 151-170$ and $170-200 \mathrm{~kg})$, no differences were observed in total born and born alive over 3 parities (Amaral Filha et al. 2008). However, the heavier gilts at first service had decreased farrowing rate in parity 2 (Table 3). On the other hand, Tummaruk et al. (2007) observed that age, BW and BT at first estrus influenced subsequent reproductive performance over the first three parities. The mean litter size was greater in gilts that had a first observed estrus between 181 and 200 days of age with $110-120 \mathrm{~kg} \mathrm{BW}$ and $13-15 \mathrm{~mm} \mathrm{BT}$. It must be pointed out that these authors worked with crossbred Landrace $x$ Yorkshire gilts that expressed their first standing estrus on average at 195 days of age, later than the usual age at puberty observed in modern commercial genotypes (Amaral Filha et al. 2009, Kummer et al. 2009).

Based on experimental data with modern genotypes and cost-benefit analysis, gilts should be inseminated at a target weight of $135-150 \mathrm{~kg}$ and at least at the second estrus (Williams et al. 2005, Kummer et al. 2006). In this way, primiparous sows should reach approximately 180 $\mathrm{kg}$ of $\mathrm{BW}$ at farrowing, this target minimizing the effects of the loss of protein mass that is still seen in many genotypes during the first lactation (Williams et al. 2005). 
Table 3. Performance over three parities for sows grouped according to growth rate or weight at first artificial insemination (Al).

\begin{tabular}{lcccccc}
\hline & \multicolumn{3}{c}{ Kummer et al. (2006) } & \multicolumn{3}{c}{ Amaral Filha et al. (2008) } \\
\cline { 2 - 7 } & \multicolumn{2}{c}{ Growth rate and age at first mating } & \multicolumn{3}{c}{ Weight at first mating, kg } \\
\cline { 2 - 7 } & $\begin{array}{c}2700 \mathrm{~g} / \mathrm{d} \\
<210 \mathrm{~d}\end{array}$ & $\begin{array}{c}\geq 700 \mathrm{~g} / \mathrm{d} \\
\geq 210 \mathrm{~d}\end{array}$ & $\begin{array}{c}<700 \mathrm{~g} / \mathrm{d} \\
\geq 210 \mathrm{~d}\end{array}$ & $130-150$ & $151-170$ & $171-200$ \\
\hline $\begin{array}{l}\text { Number of } \\
\text { females }\end{array}$ & 164 & 165 & 239 & 298 & 1007 & 421 \\
Weight at Al, $\mathrm{kg}$ & $149 \pm 9 \mathrm{a}$ & $164 \pm 8 \mathrm{~b}$ & $147 \pm 8 \mathrm{c}$ & $143 \pm 5 \mathrm{a}$ & $160 \pm 5 \mathrm{~b}$ & $177 \pm 6 \mathrm{c}$ \\
Age at Al, d & $198 \pm 6 \mathrm{a}$ & $223 \pm 8 \mathrm{~b}$ & $223 \pm 8 \mathrm{~b}$ & $211 \pm 9 \mathrm{a}$ & $219 \pm 9 \mathrm{~b}$ & $225 \pm 8 \mathrm{c}$ \\
Parity 1 & & & & & & \\
Farrowing rate, \% & $88.4 \mathrm{a}$ & $87.9 \mathrm{a}$ & $88.7 \mathrm{a}$ & $89.9 \mathrm{a}$ & $90.7 \mathrm{a}$ & $92.9 \mathrm{a}$ \\
Total born, $\mathrm{n}$ & $11.7 \pm 3.0 \mathrm{a}$ & $12.8 \pm 3.0 \mathrm{~b}$ & $11.8 \pm 3.4 \mathrm{a}$ & $12.1 \pm 2.8 \mathrm{a}$ & $12.4 \pm 2.9 \mathrm{a}$ & $12.8 \pm 3.1 \mathrm{~b}$ \\
Born alive, $\mathrm{n}$ & $10.5 \pm 3.1 \mathrm{a}$ & $11.3 \pm 2.9 \mathrm{a}$ & $10.5 \pm 3.3 \mathrm{a}$ & $11.1 \pm 2.8 \mathrm{a}$ & $11.1 \pm 3.0 \mathrm{a}$ & $11.3 \pm 3.2 \mathrm{a}$ \\
Parity 2 & & & & & & \\
Farrowing rate, \% & $84.6 \mathrm{a}$ & $86.2 \mathrm{a}$ & $89.4 \mathrm{a}$ & $88.2 \mathrm{a}$ & $79.3 \mathrm{~b}$ & $72.5 \mathrm{c}$ \\
Total born, $\mathrm{n}$ & $11.0 \pm 3.6 \mathrm{a}$ & $11.5 \pm 3.6 \mathrm{a}$ & $10.6 \pm 3.2 \mathrm{a}$ & $9.6 \pm 3.5 \mathrm{a}$ & $9.8 \pm 3.3 \mathrm{a}$ & $9.8 \pm 3.7 \mathrm{a}$ \\
Born alive, $\mathrm{n}$ & $10.6 \pm 3.5 \mathrm{a}$ & $10.7 \pm 3.2 \mathrm{a}$ & $10.1 \pm 2.9 \mathrm{a}$ & $9.1 \pm 3.5 \mathrm{a}$ & $9.3 \pm 3.2 \mathrm{a}$ & $9.2 \pm 3.5 \mathrm{a}$ \\
Parity 3 & & & & & & \\
Farrowing rate, \% & $88.2 \mathrm{a}$ & $91.1 \mathrm{a}$ & $90.2 \mathrm{a}$ & $88.1 \mathrm{a}$ & $91.5 \mathrm{a}$ & $88.9 \mathrm{a}$ \\
Total born, $\mathrm{n}$ & $12.0 \pm 3.7 \mathrm{a}$ & $12.3 \pm 3.6 \mathrm{a}$ & $12.4 \pm 3.4 \mathrm{a}$ & $11.7 \pm 2.9 \mathrm{a}$ & $11.7 \pm 3.2 \mathrm{a}$ & $12.0 \pm 3.3 \mathrm{a}$ \\
Born alive, $\mathrm{n}$ & $11.2 \pm 3.6 \mathrm{a}$ & $11.4 \pm 3.3 \mathrm{a}$ & $11.5 \pm 3.1 \mathrm{a}$ & $11.0 \pm 2.9 \mathrm{a}$ & $10.8 \pm 3.2 \mathrm{a}$ & $11.0 \pm 3.2 \mathrm{a}$ \\
\hline
\end{tabular}

Values presented as means \pm SD

$a, b, c$ in the row indicate differences among groups within each reference $(P<0.05)$.

Modern genotypes have less voluntary feed intake (Whittemore 1996), which compromises the demands for maintenance and higher milk production, resulting in body reserve mobilization. First parity sows are the most susceptible to these losses. Heavy gilts at first service tend to be heavy at farrowing with more demands for maintenance during lactation. Highest body reserve mobilization occurs in females that are heavier (Quesnel et al. 2005a) or fatter (Young et al. 2004) at farrowing. This is explained by reduced feed intake in fat sows (Revell et al. 1998, Young et al. 2004, Quesnel et al. 2005b), mainly during the first two weeks of lactation, which can be related to the circulating concentration or oxidation of nonesterified fatty acids and glycerol (Revell et al. 1998) or to an insulin resistance state in heavy sows (Quesnel et al. 2005b). Greater weights at first parity are associated with greater losses in BW and protein during lactation, however, percentages of fat loss were similar regardless of the weight at farrowing (Table 4). It has been proposed that changes in amino acid profile according to the degree of muscle protein mobilization can affect oocyte development and maturation (Clowes et al. 2003, Quesnel et al. 2005a). Moreover, responses such as decreased RNA-to-DNA ratio, increased protease gene expression and reduction of essential amino acid levels in triceps brachii muscle were magnified in primiparous sows fed to have a higher degree of protein mobilization during lactation (Clowes et al. 2005). These findings help to explain the effect of lactational catabolism on the reduction of embryo survival without affecting ovulation rate or weaning-to-estrus interval (Vinsky et al. 2006). To understand the reduction in the subsequent farrowing rate but not in the number of total born piglets that is observed in heavy females (Table 4), it would be necessary to suppose that their degree of protein mobilization had such a great impact on oocyte quality that fertilization or early embryo survival was impaired resulting in higher return to estrus rate. However, to cause return to estrus, the reduced quality of a sufficient fraction of oocytes would be required so that the number of viable embryos in the uterus would be insufficient for an appropriate signal for pregnancy recognition. Alternatively, 
breeding outcome may be influenced by an asynchrony between uterine milieu and embryonic development, which could result from changes in the embryonic or uterine proteome under the influence of protein catabolism.

Table 4. Body characteristics of primiparous sows at farrowing, body reserve mobilization during lactation and reproductive performance after weaning for gilts grouped according to weight at first farrowing ( $\pm S E$ ).

\begin{tabular}{|c|c|c|c|c|}
\hline & \multicolumn{4}{|c|}{ Groups of weight at first farrowing } \\
\hline & & Light & Intermediate & Heavy \\
\hline Number of primiparous sows & - & 376 & 805 & 379 \\
\hline \multicolumn{5}{|l|}{ Characteristics at farrowing } \\
\hline Body weight, kg & & $189 \pm 0.33 a$ & $207 \pm 0.19 b$ & $225 \pm 0.33 c$ \\
\hline (Range) & & $(167.5-197.0)$ & $(197.1-217.0)$ & $(217.1-245.0)$ \\
\hline Body fat, kg & & $43.1 \pm 0.22 \mathrm{a}$ & $48.7 \pm 0.14 b$ & $53.8 \pm 0.23 \mathrm{c}$ \\
\hline Body protein, kg & & $30.1 \pm 0.06 a$ & $33.3 \pm 0.04 b$ & $36.6 \pm 0.07 c$ \\
\hline Backfat depth, mm & & $15.9 \pm 0.13 \mathrm{a}$ & $17.1 \pm 0.09 \mathrm{~b}$ & $17.9 \pm 0.14 c$ \\
\hline Lactation length, $d$ (range $15.26 \mathrm{~d}$ ) & & $19.5 \pm 0.11 a$ & $19.7 \pm 0.07 a$ & $19.6 \pm 0.11 \mathrm{a}$ \\
\hline Total born, $\mathbf{n}$ & & $12.8 \pm 0.14 a$ & $12.5 \pm 0.10 \mathrm{a}$ & $11.9 \pm 0.17 b$ \\
\hline Born alive, $\mathrm{n}$ & & $11.7 \pm 0.13 \mathrm{a}$ & $11.4 \pm 0.10 \mathrm{a}$ & $10.8 \pm 0.16 b$ \\
\hline \multicolumn{5}{|l|}{ Body reserves mobilization } \\
\hline Body weight loss, $\%$ & & $7.9 \pm 0.22 \mathrm{a}$ & $9.3 \pm 0.15 b$ & $10.1 . \pm 0.21 \mathrm{c}$ \\
\hline Body fat loss, $\%$ & & $17.2 \pm 0.44 \mathrm{a}$ & $17.9 \pm 0.30 \mathrm{a}$ & $17.6 \pm 0.40 \mathrm{a}$ \\
\hline Body protein loss, \% & & $7.3 \pm 0.26 a$ & $8.8 \pm 0.17 b$ & $=9.8 \pm 0.25 c$ \\
\hline Backfat depth loss, mm & & $2.9 \pm 0.11 \mathrm{a}$ & $3.2 \pm 0.08 a$ & $3.2 \pm 0.13 a$ \\
\hline Weaned piglets, $n$ & & $10.5 \pm 0.05 a$ & $10.5 \pm 0.04 a$ & $10.6 \pm 0.05 a$ \\
\hline \multicolumn{5}{|l|}{ Reproductive performance after weaning } \\
\hline Weaning to estrus interval, d & & $6.1 \pm 0.18 a$ & $6.2 \pm 0.14 a$ & $5.9 \pm 0.19 a$ \\
\hline Relurn to estrus rate, \% & & $11.4 \mathrm{a}$ & $16.5 b$ & $17.7 \mathrm{~b}$ \\
\hline Adjusted farrowing rate, $\%$ & & $84.9 a$ & $80.0 \mathrm{~b}$ & $.76 .4 b$ \\
\hline Total born, $\mathrm{n}$ & & $9.3 \pm 0.19 a$ & $9.8 \pm 0.14 a b$ & $10.3 \pm 0.20 \mathrm{~b}$ \\
\hline Born alive, $n$ & & $8.9 \pm 0.18 a$ & $9.3 \pm 0.13 a b$ & $9.6 \pm 0.19 b$ \\
\hline
\end{tabular}

a, b, c $(P<0.05)$.

(Schenkel et al., unpublished observations).

\section{Effect of weight at insemination on skeletal soundness}

Gilt body condition at first mating has a significant effect on lifetime productivity. Productive performance and herd longevity can be compromised if gilts have an insufficient or excessive weight at first mating. Useful production targets might be that $85 \%$ and $75 \%$ of selected gilts should reach the first and second farrowing, respectively.

With leaner modern genotypes, pubertal BW is increased and physiological maturity is reduced. Fast growing gilts becoming overweight by the first service may be one of the major risk factors for poor retention in the herd (Williams et al. 2005). Excessive weight gain during the rearing phase may result in increased culling rate, mainly due to osteochondrosis, reducing sow longevity (Jongbloed et al. 1984, Sorenson et al. 1993). Nevertheless, this issue is still controversial, because it has been confirmed that fast growth in rearing does not impair skeletal integrity compared with slower growing pigs (Crenshaw 2003, Ytrehus et al. 2004). Most studies on osteochondrosis in pigs are performed as evaluation of lesions in slaughter animals and in some of them daily GR is not similar to that observed in the modern dam-line genotypes. Ytrehus et al. (2004) evaluated animals in different age groups and the oidest one had a gain of $600 \mathrm{~g} / \mathrm{d}$ from birth to 15 weeks of age. They found no correlation between 
osteochondrosis and weight or daily gain. However, these authors (Ytrehus et al. 2004) report that associations between osteochondrosis and rapid growth may be related with inherited traits in some populations.

Even for females comprising the breeding pool, the association between GR and removal due to lameness is still controversial. Overall retention rate over three parities was similar $(75.2$ vs. 72.4) in females with high and low GR $(\geq 700 \mathrm{~g} / \mathrm{d}$ vs. $<700 \mathrm{~g} / \mathrm{d})$ until first mating (Kummer et al. 2006) and removal for lameness at the end of three parities was not affected by GR in rearing (Young et al. 2008). However, culling rate for locomotion problems over three parities increased (Table 5) as the weight at the first mating increased (Amaral Filha et al. 2008).

Table 5. Culling reasons over three parities for sows grouped according to body weight at first mating.

\begin{tabular}{lccc}
\hline & \multicolumn{3}{c}{ Groups of weight at first mating, $\mathrm{kg}$} \\
\cline { 2 - 4 } Culling reason, $\mathrm{n}(\%)$ & $\begin{array}{r}130-150 \\
(\mathrm{n}-298)\end{array}$ & $\begin{array}{c}151-170 \\
(\mathrm{n}-1007)\end{array}$ & $\begin{array}{c}170-200 \\
(\mathrm{n}-421)\end{array}$ \\
\hline Locomotion & $18(6.0) \mathrm{a}$ & $104(10.3) \mathrm{b}$ & $64(15.2) \mathrm{c}$ \\
Reproductive & $37(12.4) \mathrm{a}$ & $104(10.3) \mathrm{a}$ & $52(12.4) \mathrm{a}$ \\
Others & $41(13.8) \mathrm{a}$ & $109(10.8) \mathrm{a}$ & $48(11.4) \mathrm{a}$ \\
\hline
\end{tabular}

$a, b, c$ in the same row indicate significant differences $(P<0.05)$.

(Amaral Filha et al. 2008).

\section{Fatness and breeding performance}

The effect of fatness on puberty attainment and productive performance is still a controversial issue. Fatness seems to be less critical than a targeted weight for puberty attainment (Foxcroft et al. 2005). Taking into account that increases in fatness are transient and any residual effects disappear by weaning of the first litter (Gill 2006), fatness at first mating seems less important than a target weight for lifetime productivity (Foxcroft et al. 2005).

While the results of some studies (Newton \& Mahan 1992, Rozeboom et al. 1995) show that the onset of puberty seems not to be controlled by a specific amount of body fat, another study (Gaughan et al. 1997) indicated that more gilts reached puberty in the group with higher BT define at selection (16-18 mm) compared to the group with a low BT (10-12 mm). Recently, Tummaruk et al. (2009) found no correlation between BT at 90 or $134 \mathrm{~kg}$ of BW with age at first estrus. In terms of productivity, whereas a clear impact of BT, measured at $100 \mathrm{~kg}$ body weight (Tummaruk et al. 2001) or at first mating (Rozeboom et al. 1996; Williams et al. 2005), on the number of piglets born in the first litter or over three parities has not been observed, gilts with a BT between 13 and $15 \mathrm{~mm}$ at the first estrus had more piglets than gilts with a BT between 11 and $13 \mathrm{~mm}$ (Tummaruk et al. 2007). More piglets were born in gilts with 16-17 $\mathrm{mm}$ of BT $(12.7 \pm 0.11)$ than in BT $10-15 \mathrm{~mm}$ gilts $(12.2 \pm 0.16)$ but no increase in total piglets born was observed in high (18-23 mm) BT gilts (12.4 \pm 0.14 ; Amaral Filha 2009).

Altogether, these observations show that BW rather than BT should be used as criterion to breed swine females. Furthermore, BW cannot be predicted by measuring BT because the pattern of increase in lean body mass differs from that of changes in BT (Williams et al. 2005, Gill 2006), which is usually weakly correlated with BW (Williams et al. 2005). Indeed, the correlation between BT and BW at mating is not significant in low GR gilts and it is lower than 0.5 in high GR gilts (Table 6). Tummaruk et al. (2009) also reported a low significant correlation between $\mathrm{BT}$ and $\mathrm{BW}(\mathrm{r}=0.27, \mathrm{P}<0.001)$ when gilts were approximately $230 \mathrm{~d}$ of age. 
Table 6. Relationship between body weight and backfat thickness at mating in gilts with different growth rates.

\begin{tabular}{lccccc}
\hline & \multicolumn{2}{c}{ Kummer et al. (a) } & \multicolumn{3}{c}{ Amaral Filha et al. (b) } \\
\cline { 2 - 6 } & $492-656 \mathrm{~g} / \mathrm{d}$ & $658-800 \mathrm{~g} / \mathrm{d}$ & $600-700 \mathrm{~g} / \mathrm{d}$ & $701-770 \mathrm{~g} / \mathrm{d}$ & $771-870 \mathrm{~g} / \mathrm{d}$ \\
& $n-43$ & $n-55$ & $n-345$ & $n-710$ & $n-366$ \\
\hline Correlation coefficient & 0.27 & 0.45 & -0.016 & 0.090 & 0.11 \\
P value & 0.079 & 0.0005 & 0.771 & 0.017 & 0.038 \\
\hline
\end{tabular}

(a) Growth rate from birth until approximately $144 \mathrm{~d}$ of age.

(b) Growth rate from birth until first mating.

(Amaral Filha et al. and Kummer et al., unpublished observations)

\section{Conclusions}

It is important to recognize that physiological characteristics of contemporary females are different from old genotypes thereby traditional management practices that were established in the past should be re-evaluated. The comprehension of the interaction among body characteristics and puberty attainment, productivity performance and longevity is still limited. It seems that these interactions change with time and it is also expected that some peculiarities exist among the wide variety of genotypes. It is difficult to discern the real effects of age, weight, backfat and estrus number at first insemination on reproductive performance and longevity, because these variables are associated among themselves. Age at boar exposure interacts with GR to influence age at puberty. Higher lifetime GR gilts ( $>700 \mathrm{~g} / \mathrm{d}$ ) attain puberty earlier and have a lower anoestrus rate after boar exposure for puberty stimulation. Gilts that attain the breeding target weight (135-150 kg) with at least one previously recorded estrus and that are adapted to herd health status can be inseminated irrespective of age and backfat level. Piglet production at first parity may be increased in gilts with a high GR but the number of stillborns can also increase. Excessive weight at first breeding or first farrowing should be avoided. The culling rate for locomotion problems over 3 parities can be increased in these gilts.

\section{Acknowledgements}

The authors acknowledge the support of Brazilian National Council of Technological and Scientific Development (Conselho Nacional de Desenvolvimento Científico e Tecnológico $\mathrm{CNPq}$ ) for their financial support.

\section{References}

Amaral Filha WS, Schenkel AC, Seidel E, Bernardi ML, Wentz I \& Bortolozzo FP 2008 Sow productivity over three parities according to weight at first service. $p$ 442 Proceedings of the $20^{\text {th }}$ IPVS Congress, Durban, South Africa.

Amaral Filha WS 2009 Reflexo da taxa de crescimento em leitoas e do peso na primeira inseminaçāo sobre o desempenho reprodutivo subseqüente e longevidade da matriz PhD Thesis Universidade Federal do Rio Grande do Sul, Porto Alegre, Brazil.

Amaral Filha WS, Bernardi ML, Wentz I \& Bortolozzo FP 2009 Growth rate and age at boar exposure as factors influencing gilt puberty. Livestock Science 120 51-57.

Beltranena E, Aherne FX \& Foxcroft GR 1993 Innate variability in sexual development irrespective of body fatness in gilts. Journal of Animal Science 71 $471-480$.

Beltranena E, Aherne FX, Foxcroft GR \& Kirkwood RN 1991 Effects of pre-and postpubertal feeding on production traits at first and second estrus in gilts. Journal of Animal Science 69 886-893.

Clowes EJ, Aherne FX, Shaefer Al., Foxcroft GR \& Baracos VE 2003 Parturition body protein loss during lactation influence performance during lactation and ovarian function at weaning in first-parity sows. Journal of Animal Science 81 1517-1528.

Clowes EJ, Aherne FX \& Baracos VE 2005 Skeletal muscle protein mobilization during the progression of lactation. American lournal of Physiology Endocrinology and 
Metabolism 288 E564-E572.

Crenshaw TD 2003 Nutritional manipulation of bone mineralization in developing gilts. p 183-189 Proceedings of the 2003 Allen D Leman Swine Conference, Saint Paul, Minnesota.

Evans ACO \& O 'Doherty JV 2001 Endocrine changes and management factors affecting puberty in gilts. Livestock Production Science 68 1-12.

Foxcroft GR \& Aherne FX 2001 Rethinking management of the replacement gilt. Advances in Pork Production 12 197-210.

Foxcroft GR, Beltranena E, Patterson I \& Williams N 2005 The biological basis for implementing effective replacement gilt management. p 5-25 Proceedings of Allen D Leman Swine Pre-Conference Reproduction 'Workshop, Saint Paul, Minnesota.

Gaughan JB, Cameron RD, Dryden GM \& Young BA 1997 Effect of body composition at selection on reproductive development in large white gilts. Journal of Animal Science 75 1764-1772.

Gill BP 2006 Body composition of breeding gilts in response to dietary protein and energy balance from thirty kilograms of body weight to completion of first parity. Journal of Animal Science 84 1926-1934.

Gondret F, Lefaucheur L, Louveau I, Lebret B, Pichodo $X \&$ Le Cozler Y 2005 Influence of piglet birth weight on postnatal growth performance, tissue lipogenic capacity and muscle histological traits at market weight. Livestock Production Science 93 137-146.

Hughes PE 1982 Factors affecting natural attainment of puberty in the gilt. In Control of Pig Reproduction, pp 161-177. Eds DJA Cole \& GR Foxcroft. London: Butterworths.

Jongbloed AW, Diepen JTM \& Hopman LCC 1984 The influence of energy level during rearing of breeding sows on longevity and lifetime production. Internal Report 169, Institute for livestock feeding and nutrition research, Lelystadt, The Netherlands.

King RH 1989 Effect of live weight and body composition of gilts at 24 weeks of age on subsequent reproductive efficiency. Animal Production 49 109-115.

Kirkwood RN \& Aherne FX 1985 Energy intake, body composition and reproductive performance of the gilt. lournal of Animal Science $601518-1529$.

Kirkwood RN \& Thacker PA 1992 Management of replacement breeding animals. Veterinary Clinics of North America: Food Animal Practice 8 575-587.

Kummer R, Bernardi ML, Schenkel AC, Amaral Filha WS, Wentz I \& Bortolozzo FP 2009 Reproductive performance of gilts with similar age but with different growth rate at the onset of puberty stimulation. Reproduction in Domestic Animals 44 255-259.

Kummer R, Bernardi ML, Wentz I \& Bortolozzo FP 2006 Reproductive performance of high growth rate gilts inseminated at an early age. Animal Reproduction Science 96 47-53.

Milligan BN, Dewey CE \& Grau AF 2002 Neonatalpiglet weight variation and its relation to pre-weaning mortality and weight gain on commercial farms. Preventive Veterinary Medicine 56 119-127.
Muirhead MR \& Alexander TJL 1997 Reproduction: non infectious infertility. In Managing Pig Health and Treatment of Disease, pp133-161. Eds Muirhead MR \& Alexander TJL. Sheffield: $5 \mathrm{M}$ Enterprises.

Newton EA \& Mahan DC 1992 Effect of feed intake during late development on pubertal onset and resulting body composition in crossbred gilts. Journal of Animal Science 70 3774-3780.

Patterson JL, Ball RO, Willis HJ, Aherne FX \& Foxcroft GR 2002 The effect of lean growth rate on puberty attainment in gilt. Journal of Animal Science $\mathbf{8 0}$ 1299-1310.

Prunier A, Bonneau M \& Etienne M 1987 Effects of age and live weight on the sexual development of gilts and boars fed two planes of nutrition. Reproduction Nutrition Development 27 689-700.

Quesnel H, Mejia-Guadarrama CA, Dourmad J-Y, Farmer C \& Prunier A 2005b Dietary protein restriction during lactation in primiparous sows with different live weights at farrowing: I. Consequences on sow metabolic status and litter growth. Reproduction Nutrition Development 45 39-56.

Quesnel H, Mejia-Guadarrama CA, Pasquier A, Dourmad J-Y \& Prunier A 2005a Dietary protein restriction during lactation in primiparous sows with different live weights at farrowing: II. Consequences on reproductive performance and interactions with metabolic status. Reproduction Nutrition Development 45 57-68.

Quiniou N, Dagorn J \& Gaudré D 2002 Variation of piglets' birth weight and consequences on subsequent performance. Livestock Production Science 7863 . 70.

Revell DK, Williams IH, Mullan BP, Ranford JL \& Smits RJ 1998 Body composition at farrowing and nutrition during lactation affect the performance of primiparous sows: I. Voluntary feed intake, weight loss, and plasma metabolites. Journal of Animal Science 76 1729-1737.

Rozeboom DW, Pettigrew JE, Moser RL, Cornelius SG \& El Kandelgy SM 1995 Body composition of gilts at puberty. Journal of Animal Science $732524-2531$.

Rozeboom DW, Pettigrew JE, Mosel RL, Cornelius SG \& El Kandelgy SM 1996 Influence of gilt age and body composition at first breeding on sow reproductive performance and longevity. Journal of Animal Science 74 138-150.

Sorenson M, Jorgensen B \& Danielsen V 1993 Different feeding intensity of young gilts: effect on growth, milk yield reproduction, leg soundness and longevity. 20p. Report 14, National Institute of Animal Science, Denmark.

Tummaruk P, Lundeheim N, Einarsson S \& Dalin A-M 2001 Effect of birth litter size, birth parity number, growth rate, backfat thickness and age at first mating of gilts on their reproductive performance as sows. Animal Reproduction Science 66 225-237.

Tummaruk $P$, Tantasuparuk $W$, Techakumphu $M \&$ Kunavongkrit A 2007 Age, body weight and backfat thickness at first observed oestrus in crossbred Landrace $x$ Yorkshire gilts, seasonal variations and their 
influence on subsequence reproductive performance. Animal Reproduction Science 99 167-181.

Tummaruk P, Tantasuparuk W, Techakumphu M \& Kunavongkrit A 2009 The association between growth rate, body weight, backfat thickness and age at first observed oestrus in crossbred Landrace $\mathrm{x}$ Yorkshire gilts. Animal Reproduction Science 110 108-122.

Van Wettere WHEJ, Revell DK, Mitchell M \& Hughes PE 2006 Increasing the age of gilts at first boar contact improves the timing and synchrony of the pubertal response but does not affect potential litter size. Animal Reproduction Science 95 97-106.

Vinsky MD, Novak S, Dyck MK, Dixon WT \& Foxcroft GR 2006 Nutritional restriction in lactating primiparous sows selectively affects female embryo survival and overall litter development. Reproduction, Fertility \& Development 18 347-355.

Whittemore CT 1996 Nutrition reproduction interactions in primiparous sows. Livestock Production Science 46 65-83.

Williams NH, Patterson J \& Foxcroft GR 2005 Nonnegotiables in gilt development. Advances in Pork Production 16 281-289.
Wolf J, Záková E \& Groeneveld E 2008 Within-litter variation of birth weight in hyperprolific Czech Large White sows and its relation to litter size traits, stillborn piglets and losses until weaning. Livestock Science 115 195-205.

Young MG, Tokach MD, Aherne FX, Dritz SS, Goodband RD, Nelssen JL \& Loughin TM 2004 Comparison of three methods of feeding sows in gestation and the subsequent effects on lactation performance. lournal of Animal Science 82 3058-3070.

Young MG, Tokach MD, Aherne FX, Dritz SS, Goodband RD, Nelssen JL \& Loughin TM 2008 Effect of space allowance during rearing and selection criteria, on performance of gilts over three parities, in a commercial swine production system. Journal of Animal Science 86 3181-3193.

Ytrehus B, Carlson CS, Lundeheim N, Mathisen L, Reinholdt FP, Teige j \& Ekman S 2004 Vascularisation and osteochondrosis of the epiphyseal growth cartilage of the distal femur in pigs-development with age, growth rate, weight and joint shape. Bone 34 454465. 